\title{
Earliness and Blooming Time in the Tulip Collection of "Al. Borza" Botanical Garden, Cluj-Napoca, Romania
}

\author{
Mirela Irina CORDEA ${ }^{1 *}$ and Angela Doina PUI ${ }^{2}$ \\ ${ }^{1}$ Faculty of Horticulture. University of Agricultural Sciences and Veterinary Medicine Cluj-Napoca, \\ Romania. \\ ${ }^{2}$ Al. Borza Botanical Garden Cluj-Napoca, Romania. \\ *)Corresponding author, e-mail: mcordea@usamvcluj.ro \\ BulletinUASVM Horticulture 72(2) / 2015 \\ Print ISSN 1843-5254, Electronic ISSN 1843-5394 \\ DOI:10.15835/buasvmcn-hort:11662
}

\begin{abstract}
The present paper reveals the results of a study on the tulip collection in the environmental conditions of "Al. Borza" Botanical Garden Cluj-Napoca, concerning two characteristics: earliness of flowering and blooming time. Most tulip cultivars are originated in the Netherlands where environmental conditions are different from those in Cluj-Napoca. The tulip collection of "Alexandru Borza" Botanical Garden of Cluj-Napoca has been set up in order to maintain its decorative value as long as possible. In this regard, there were planted cultivars with various ranges of earliness of flowering and long duration of blooming period. Flowering time of the tulips, which make up the "Alexandru Borza" Botanical Garden of Cluj-Napoca collection last between 6-22 days. The blooming period of these cultivars is not as homogenous within the groups as expected, each group exhibiting cultivars with shorter or longer flowering period than the mean of experiment. The main objective of this study was to identify the genetic sources for earliness and blooming period, which could be used in a breeding program for early flowering tulips, as it is stated by most of the important tulip breeding.
\end{abstract}

Keywords: breeding, earliness, flowering, tulip.

\section{${ }^{*}$ INTRODUCTION}

The "Alexandru Borza" Botanical Garden of Cluj-Napoca is located at 380-420 m altitude on a slight slope with $\mathrm{N}, \mathrm{N}-\mathrm{E}$ and $\mathrm{N}-\mathrm{V}$ expositions, having a rather earlier spring than the surrounding districts. Its $8.8^{\circ} \mathrm{C}$ yearly mean temperature favors the development of vernal plants as tulips.

As Demir et al. (2012) mentioned, the climatic conditions are very important for tulip cultivation when grown outdoor, terms in which the "Al. Borza" Botanical Garden Cluj-Napoca collection was also set up.

Tulips are considered the most beautiful flowers of spring, comprising over 150 species, with about 5600 cultivars (Cristea, 2014). The tulip collection of "Al. Borza" Botanical Garden, Cluj-Napoca is a traditional one, being created in
1920, when the botanical garden was established. In all these years, the collection has been enriched, comprising today 141 cultivars and two botanical species of tulips.

Breeders classified (Brickell and Zuk, 1997; Raamsdonk and de Vries, 1996) the tulip cultivars in 16 groups or divisions, regarding the period of flowering and flower appearance, in: Single early tulips, Double early tulips, Triumph tulips, Darwin hybrid tulips, Single late tulips, Lily-flowered tulip, Fringed tulips, Viridiflora tulips, Rembrandt tulips, Parrot tulips, Double late tulips, Kaufmanniana tulips, Fosteriana tulips, Greigii tulips, Botanical species tulips, Multiflowering tulips.

In the "Al. Borza" Botanical Garden tulip collection, all these groups are represented as shown in Tab. 1 . The largest number of cultivars 
is in the group III (Triumph tulips) with 29 cultivars, the following one, in decreasing number of representatives is group VII (Fringed tulips) with 14 cultivars etc., with a total number of 141 cultivars. Additionally, there are also two botanical tulip species (Botanical tulip species) and group IX 'Rembrandt tulips' with a mix of plants.

A more important character is the number of days the flower maintains its ornamental value (Eijk and Eikelboom, 1980), especially in the ornamental sector of a botanical garden or in landscape architecture.

\section{MATERIALS AND METHODS}

The observations were performed in the "Al. Borza" Botanical Garden Cluj-Napoca tulip collection organized in 16 groups of cultivars according to classification published by Brickell and Zuk, 1997; Raamsdonk and de Vries, 1996, in the spring of 2015, concerning the date of beginning and end of flowering. The collection amounts to 141 cultivars and two species of tulips which find proper growing conditions in ClujNapoca environment.

For each cultivar 10 plants were studied recording the date on which the flower buds showed their colour and end of flowering when the perianth dropped. These data allowed the computation of earliness of flowering (no. of days from March 20, 2015) and the blooming period (days).

The analysis of variance and LDS test were used to statically differentiate the tested tulip cultivars as far as the two interested characters were concerned, the mean of cultivars being considered as control (Ardelean et al., 2007). In the analyzed collection, to establish if there is a correlation between earliness and the blooming period in the studied genotypes, the correlation coefficient (r) between these two characteristics was computed.

Consequently the best ten cultivars as far as the two analysed characters are concerned will be introduced in a crossing process which will be the first step in a breeding program for early flowering tulips, as it is stated by most of the important tulip breeding (Tuyl and Creij, 2006).

\section{RESULTS AND DISCUSSION}

The two studied characters (earliness and the blooming time) are very important regarding the tulips decorative effect. As far as they represent the splendor of spring, early flowering and its long duration are desirable. On the other hand, a collection is supposed to contain plants with different periods of flowering so that their decorative period may extend as long as possible.

Analyzing the data on earliness of flowering, in the 16 tulip groups of "Al. Borza" Botanical Garden Cluj-Napoca collection, it is obvious that the earliest cultivars belong to groups IV (Darwin hybrid tulips), XII (Kaufmanniana tulips), XIII (Fosteriana tulips) and XIV (Greigii tulips). In these groups most of the cultivars presented earlier flowering than the mean of cultivars (Tab.1).

As its name proves, "The First" was the earliest cultivar (onset of flowering on March, 23) followed, on March, 26 by 'Heart's Delight' from group XII - Kaufmanniana tulips and 'Quebec' from group XIV - Greigii tulips. These results might be considered quite surprising since there was expected a significant precocity of flowering in cultivars of the first two groups 'Single early tulips' and 'Double early tulips', as these groups are named and classified.

The latest flowering cultivars were in groups V - Single late tulips, VI - Lily-flowered tulip, VII - Fringed tulips, VIII - Viridiflora tulips, X - Parrot tulips and XI - Double late tulips. 'Pinses Irene' presents late flowering although it belongs to group I - Single early tulips, suggesting that in some genotypes the earliness of flowering might be seriously influenced by the climatic conditions.

Results on blooming time in the studied tulip collection there show that in group IV - Darwin hybrid, two cultivars: 'American Dream' with 45 blooming days and 'Hakuun' with 34 blooming days, presented the longest period of flowering. It is to be noted that 'The First', with the earliest flowering date also presents a rather long blooming time (22 days).

As stated by Eijk et al., (1977), in tulip, high ornamental value cultivars are considered those with more than six days of blooming time. According to our results, 'West Point' from group VI (Lily-flowered tulip) with only 6 days and 'Prinses Irene' from the first group (Single early tulips) with 7 days presented also the shortest flowering period. These cultivars present a poor decorative value in our environmental conditions.

A main goal of this study was to find out if there is a correlation between the onset of flowering 
and its duration. The correlation coefficients (r) between the two studied characters presented the most undesirable values in group XII Kaufmanniana tulips, where earliness of flowering was significantly correlated with short duration of blooming period in 'Scarlet Baby' $\left(\mathrm{r}=0.98^{* *}\right)$,
'Hearth's Delight' (r=0.64*) and 'Ice Stick' ( $\left.r=0.62^{*}\right)$ cultivars (Tab.1).

The same effect was registered in 'Hatsuzakura' ( $\mathrm{r}=0.71^{*}$ ) and 'Christmas Marvel' $\left(\mathrm{r}=0.69^{*}\right)$ cultivars of the first listed group I - Single early tulips.

Tab. 1. Earliness characteristics of the studied tulip collection

\begin{tabular}{|c|c|c|c|c|c|c|c|}
\hline \multirow{2}{*}{ Groups } & \multirow{2}{*}{$\begin{array}{l}\text { Cultivars } \\
\text { Baby Blue }\end{array}$} & \multicolumn{2}{|c|}{$\begin{array}{c}\text { Earliness of } \\
\text { flowering }\end{array}$} & \multicolumn{2}{|c|}{ Blooming time } & \multicolumn{2}{|c|}{$\begin{array}{c}\text { Correlation } \\
\text { coefficient }\end{array}$} \\
\hline & & 25 & 0 & 19 & $*$ & -0.70 & o \\
\hline \multirow{8}{*}{$\begin{array}{c}\text { I. } \\
\text { Single early tulips }\end{array}$} & Christmas Marvel & 10 & 000 & 18 & & 0.69 & * \\
\hline & Couleur Cardinal & 25 & o & 19 & $*$ & -0.09 & \\
\hline & Hermitage & 31 & $*$ & 17 & o & -0.15 & \\
\hline & White Marvel & 28 & & 18 & & -0.13 & \\
\hline & Yokohama & 24 & 0 & 17 & 0 & -0.14 & \\
\hline & Apricot Magic & 21 & 000 & 18 & & 0.22 & \\
\hline & Merry Christmas & 28 & & 15 & 000 & 0.28 & \\
\hline & Prinses Irene & 37 & $* * *$ & 7 & 000 & -0.33 & \\
\hline \multirow{12}{*}{$\begin{array}{c}\text { II. } \\
\text { Double early tulips }\end{array}$} & Abba & 28 & & 19 & $*$ & 0.11 & \\
\hline & La Belle Epoque & 31 & $*$ & 19 & $*$ & 0.24 & \\
\hline & Mondial & 21 & 000 & 18 & & 0.33 & \\
\hline & Monsella & 29 & & 18 & & 0.37 & \\
\hline & Monte Carlo & 28 & & 18 & & 0.35 & \\
\hline & Orange Princess & 21 & 000 & 18 & & 0.28 & \\
\hline & Queen of Marvel & 13 & 000 & 20 & $* *$ & -0.02 & \\
\hline & David Teniers & 27 & & 19 & $*$ & 0.40 & \\
\hline & Eternal Flame & 26 & & 19 & $*$ & -0.16 & \\
\hline & Peach Blossom & 27 & & 18 & & 0.25 & \\
\hline & Willem Van Orange & 26 & & 19 & $*$ & 0.26 & \\
\hline & Willemsoord & 28 & & 17 & 0 & 0.35 & \\
\hline \multirow{15}{*}{$\begin{array}{l}\text { III. } \\
\text { Triumph tulips }\end{array}$} & Annie Schilder & 27 & & 16 & oo & 0.14 & \\
\hline & Apricot Foxx & 13 & 000 & 18 & & -0.50 & \\
\hline & Arie Hoek & 27 & & 18 & & -0.68 & o \\
\hline & Boston & 24 & 0 & 17 & 0 & 0.13 & \\
\hline & Brown Sugar & 30 & & 18 & & 0.56 & \\
\hline & Carnaval de Rio & 41 & $* * *$ & 18 & & -0.72 & o \\
\hline & Escape & 28 & & 17 & 0 & -0.50 & \\
\hline & Fontainebleau & 26 & & 18 & & -0.12 & \\
\hline & Guus Papendrecht & 24 & o & 17 & 0 & 0.25 & \\
\hline & Havran & 25 & 0 & 16 & 00 & 0.37 & \\
\hline & Negrita & 35 & $* * *$ & 18 & & 0.13 & \\
\hline & Paul Scherer & 26 & & 17 & o & -0.27 & \\
\hline & Pretty Princess & 26 & & 17 & o & -0.03 & \\
\hline & Recreado & 24 & 0 & 17 & 0 & 0.13 & \\
\hline & Rems Favourite & 29 & & 17 & 0 & 0.05 & \\
\hline
\end{tabular}




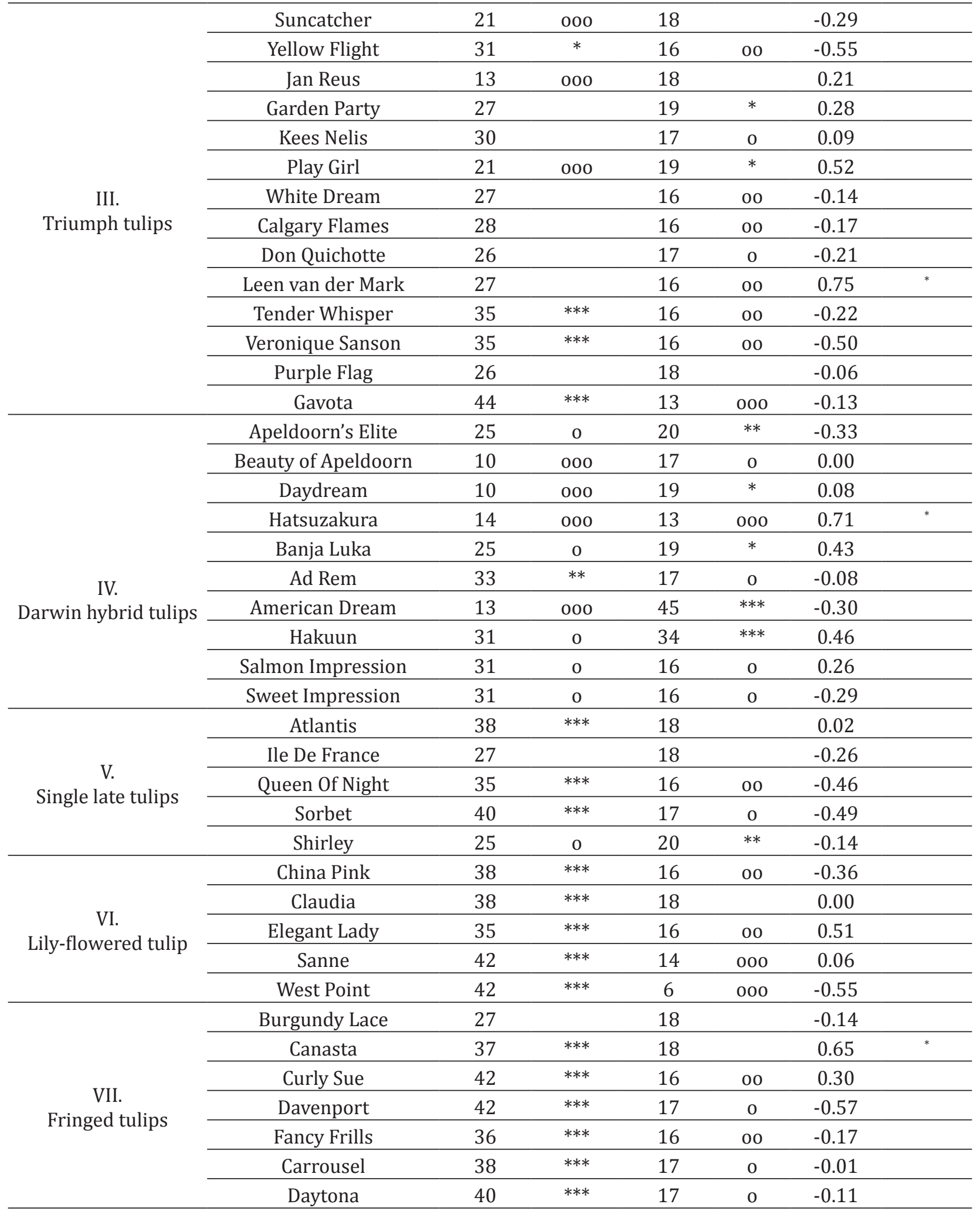




\begin{tabular}{|c|c|c|c|c|c|c|c|}
\hline \multirow{7}{*}{$\begin{array}{c}\text { VII. } \\
\text { Fringed tulips }\end{array}$} & Lambada & 37 & $* * *$ & 19 & $*$ & -0.38 & \\
\hline & Mascotte & 38 & $* * *$ & 17 & 0 & -0.13 & \\
\hline & Oviedo & 35 & $* * *$ & 18 & & 0.03 & \\
\hline & Queensland & 36 & $* * *$ & 18 & & 0.68 & $*$ \\
\hline & Fringed Family & 37 & $* * *$ & 18 & & 0.06 & \\
\hline & Valery Gergiev & 37 & $* * *$ & 17 & 0 & 0.33 & \\
\hline & Sensual Touch & 35 & $* * *$ & 19 & $*$ & -0.24 & \\
\hline \multirow{5}{*}{$\begin{array}{l}\text { VIII. } \\
\text { Viridiflora tulips }\end{array}$} & China Town & 38 & $* * *$ & 15 & 000 & -0.36 & \\
\hline & Esperanto & 38 & $* * *$ & 18 & & -0.56 & \\
\hline & Golden Artist & 38 & $* * *$ & 17 & o & -0.39 & \\
\hline & Nightrider & 39 & $* * *$ & 21 & $* * *$ & -0.03 & \\
\hline & Spring Green & 39 & $* * *$ & 18 & & -0.27 & \\
\hline IX. Rembrandt tulips & Mix & 31 & $*$ & 18 & & 0.05 & \\
\hline \multirow{12}{*}{$\begin{array}{c}\text { X. } \\
\text { Parrot tulips }\end{array}$} & Apricot Parrot & 39 & $* * *$ & 17 & o & 0.33 & \\
\hline & Black Parrot & 42 & $* * *$ & 17 & 0 & -0.52 & \\
\hline & Estella Rijnveld & 38 & $* * *$ & 17 & 0 & 0.43 & \\
\hline & Topparrot & 38 & $* * *$ & 18 & & -0.17 & \\
\hline & Orange Favourite & 26 & - & 23 & $* * *$ & -0.21 & \\
\hline & Parrot King & 35 & $* * *$ & 18 & & 0.08 & \\
\hline & Professor Röntgen & 35 & $* * *$ & 18 & & 0.19 & \\
\hline & Super Parrot & 37 & $* * *$ & 18 & & -0.04 & \\
\hline & Texas Flame & 40 & $* * *$ & 17 & o & 0.50 & \\
\hline & Green Wave & 41 & $* * *$ & 17 & 0 & -0.24 & \\
\hline & Libretto Parrot & 28 & - & 16 & oo & -0.19 & \\
\hline & Blue Parrot & 38 & $* * *$ & 16 & oo & 0.00 & \\
\hline \multirow{13}{*}{$\begin{array}{c}\text { XI. } \\
\text { Double late tulips }\end{array}$} & Abigail & 39 & $* * *$ & 18 & & 0.17 & \\
\hline & Akebono & 39 & $* * *$ & 16 & oo & -0.19 & \\
\hline & Angélique & 38 & $* * *$ & 17 & o & 0.01 & \\
\hline & Black Hero & 39 & $* * *$ & 18 & & -0.22 & \\
\hline & Blue Diamond & 39 & $* * *$ & 18 & & 0.05 & \\
\hline & Carnaval De Nice & 38 & $* * *$ & 18 & & -0.32 & \\
\hline & Drumline & 38 & $* * *$ & 16 & oo & 0.09 & \\
\hline & Queensday & 41 & $* * *$ & 17 & o & -0.42 & \\
\hline & Verona & 43 & $* * *$ & 18 & & 0.21 & \\
\hline & Sweet Desire & 35 & $* * *$ & 16 & oo & -0.51 & \\
\hline & Maureen Double & 45 & $* * *$ & 19 & $*$ & 0.19 & \\
\hline & Renown Unique & 44 & $* * *$ & 17 & 0 & -0.43 & \\
\hline & Uncle Tom & 36 & $* * *$ & 17 & 0 & 0.70 & $*$ \\
\hline \multirow{7}{*}{$\begin{array}{c}\text { XII. } \\
\text { Kaufmanniana tulips }\end{array}$} & Heart's Delight & 6 & 000 & 16 & oo & 0.64 & * \\
\hline & Ice Stick & 12 & 000 & 16 & oo & 0.62 & * \\
\hline & Love Song & 7 & 000 & 18 & & 0.43 & \\
\hline & Scarlet Baby & 13 & 000 & 13 & 000 & 0.98 & ** \\
\hline & Showwinner & 7 & 000 & 18 & & -0.07 & \\
\hline & Stresa & 11 & 000 & 17 & 0 & -0.48 & \\
\hline & The First & 3 & 000 & 22 & $* * *$ & 0.11 & \\
\hline
\end{tabular}




\begin{tabular}{|c|c|c|c|c|c|c|}
\hline \multirow{6}{*}{$\begin{array}{l}\text { XIII. } \\
\text { Fosteriana tulips }\end{array}$} & Orange Emperor & 16 & 000 & 17 & o & -0.21 \\
\hline & Princeps & 11 & ooo & 16 & oo & -0.13 \\
\hline & Yellow Purissima & 25 & o & 18 & & -0.16 \\
\hline & Pirand & 19 & ooo & 16 & oo & -0.23 \\
\hline & Purissima & 13 & ooo & 18 & & -0.30 \\
\hline & Solva & 13 & ooo & 17 & o & -0.43 \\
\hline \multirow{8}{*}{$\begin{array}{c}\text { XIV. } \\
\text { Greigii tulips }\end{array}$} & Cape Cod & 24 & 0 & 17 & o & 0.01 \\
\hline & Quebec & 6 & 000 & 20 & $* *$ & -0.25 \\
\hline & Royal Anthos & 21 & 000 & 17 & 0 & 0.22 \\
\hline & Sweet Lady & 7 & 000 & 22 & $* * *$ & -0.13 \\
\hline & Red Riding Hood & 24 & 000 & 17 & o & 0.31 \\
\hline & Mary Ann & 10 & 000 & 16 & 00 & -0.45 \\
\hline & Toronto & 11 & 000 & 16 & 00 & -0.30 \\
\hline & Flowerdale & 10 & 000 & 16 & 00 & -0.11 \\
\hline \multirow{2}{*}{$\begin{array}{l}\text { XV. Botanical } \\
\text { tulip species }\end{array}$} & Tulipa linifolia & 21 & 000 & 20 & $* *$ & -0.43 \\
\hline & Tulipa tarda & 24 & 0 & 17 & 0 & -0.32 \\
\hline \multirow{5}{*}{$\begin{array}{c}\text { XVI. } \\
\text { Multiflowering tulips }\end{array}$} & Candy Club & 37 & $* * *$ & 16 & 00 & 0.31 \\
\hline & Praestans Unicum & 14 & 000 & 12 & 000 & 0.07 \\
\hline & Jetfire & 7 & 000 & 19 & $*$ & 0.45 \\
\hline & Antoinette & 43 & $* * *$ & 16 & oo & 0.11 \\
\hline & Gipsy Love & 44 & $* * *$ & 16 & oo & 0.08 \\
\hline $\begin{array}{ll}\mathrm{LSD}_{5 \%}= & 3 \\
\mathrm{LSD}_{1 \%}= & 5 \\
\mathrm{LSD}_{0.1 \%}= & 6\end{array}$ & $\mathrm{DF}=10\left(\mathrm{r}_{5 \%}=0.63 ; \mathrm{r}_{1 \%}=0.76\right.$ & & & & & \\
\hline
\end{tabular}

The late flowering of 'Carnaval de Rio' $\left(\mathrm{r}=0.72^{\circ}\right)$ of group III - Triumph tulips is also negatively correlated with the blooming time.

Data presented in Table 1 show that in most of the studied cultivars there is no significant correlation between earliness and the blooming time.

\section{CONCLUSION}

According to our data, the studied collection comprises several cultivars with a very early flowering and reasonable long period of blooming (i.e. 'Christmas Marvel', group I, 'Hart's delight', 'Ice stick', group XII) which could be used as genitors in breeding early flowering tulips with a long last blooming period.

The most peculiar behavior in the climatic conditions of the "Alexandru Borza" Botanical Garden of Cluj-Napoca presented the cultivars of group XII, especially 'The First', which were rather early in flowering and with a considerably long blooming period -22 days.

Group XII - Kaufmanniana tulips may be categorized, in the climatic conditions taken into consideration, as being the earliest cultivars with an average or long blooming period.

Groups XII (Kaufmanniana tulips), XIII (Fosteriana tulips) and XIV (Greigii tulips) include the cultivars with the most flowering precocity while groups VI - Lily-flowered tulip, VII - Fringed tulips, VIII - Viridiflora tulips, X - Parrot tulips and XI - Double late tulips contain the latest flowering cultivars.

Both analyzed characters of the tulips planted in "Alexandru Borza" Botanical Garden of ClujNapoca climatic conditions allow the possibility to identify certain genitors that may be used for obtaining new Romanian tulip cultivars.

\section{REFERENCES}

1. Ardelean M, Sestras R, Cordea M (2007). Horticultural Experimental Design. Ed. AcademicPres Cluj-Napoca.

2. Brickell C, Zuk J (1997). The American Horticultural Society A-Z encyclopedia of garden plants. New York.

3. Cristea V (2014). Vascular plants: diversity, systematic, ecology and importance. Ed. Cluj University Press, ClujNapoca.

4. Demir K, Baskent A, Halloran N (2012). Effects of different substrates on growth of tulip bulbs under ring culture, Acta.Hort. 937:971-975. 
5. EijkJPvan, Eikelboom W, Sparnaaij LD (1977). Possibilities of selection for keeping quality in tulip breeding.2, Euphytica (26):825-828.

6. Eijk JP van, Eikelboom W (1980). Methods of selection in tulip breeding, Acta Horticulturae (109):217-225.

7. Cultivar classification in Tulipa L. (Liliaceae). Acta Bot. Neerl. 45: 183-198.
8. Tuyl JM, Creij MGM van (2006). Tulip: Tulipa gesneriana and Tulipa hybrids. In: Flower Breeding and Genetics Issues, Challenges and Opportunities for the 21st Century (ed. Anderson, N. O.), Ed. Springer. 